\title{
Activation of Toll-like receptor-2 by tumor associated matrix metalloproteinase-2 modulates dendritic cell function
}

\author{
Emmanuelle Godefroy ${ }^{1}$, Nina Bhardwaj ${ }^{2^{*}}$ \\ From Society for Immunotherapy of Cancer 29th Annual Meeting \\ National Harbor, MD, USA. 6-9 November 2014
}

Matrix metalloproteinases (MMPs) are zinc-dependent endopeptidases which degrade extracellular matrix proteins and modulate cell proliferation, migration, differentiation and angiogenesis. MMP-2, a member of the gelatinase subfamily of MMPs, participates in the remodeling and resolution of tissue injury and tumorigenesis. We recently identified an unexpected new role for MMP2 in the modulation of innate immune function and in the differentiation of inflammatory $\mathrm{T}_{\mathrm{H}} 2$ responses in the tumor microenvironment [1]. Pre-exposure to MMP-2 inhibits IL-12 function and up-regulates OX40L expression by human dendritic cells (DCs). Enzymatically active MMP-2 causes degradation of the IFNAR1 chain of the type-I IFN receptor, reducing the ability of IFN beta to enhance transcription of the IL-12p35 subunit through STAT1 phosphorylation. In the absence of IL-12, OX40L now functions as a key co-stimulatory molecule for the priming of $\mathrm{T}_{\mathrm{H}} 2$ cells. Indeed, we have identified $\mathrm{T}_{\mathrm{H}} 2$ cells within the TIL compartment of melanoma specimens that produce IL-4, TNF and IL-13. However, the $\mathrm{T}_{\mathrm{H}} 2$ mechanism by which MMP-2 up-regulates OX40L is not known and the role of MMP-2-driven $\mathrm{T}_{\mathrm{H}} 2$ cells in vivo has not been determined. In this study, we specifically investigated how MMP-2 up-regulates OX40L on DCs to drive type-2 polarization and the physiologic role of MMP-2 imprinted DC in driving $\mathrm{T}_{\mathrm{H}} 2$ cells. We identified a novel physiological receptor, namely TLR2, for MMP-2 on DCs that, upon activation, up regulates OX40L and induces the production of TNF and IL-6. Significantly, MMP-2 acted as an adjuvant to prime $\mathrm{TH} 2$ cells in vivo towards protein antigens. Therefore, extracellular MMP2 including that derived from tumors has the potential to

${ }^{2}$ Icahn School of Medicine at Mt Sinai, NY, NY, USA

Full list of author information is available at the end of the article locally affect DCs leading to modulation of immune responses in malignant diseases.

\section{Authors' details}

${ }^{1}$ New York Blood Center LFKRI, New York, NY, USA. ${ }^{2}$ Icahn School of Medicine at Mt Sinai, NY, NY, USA.

Published: 6 November 2014

\section{Reference}

1. Godefroy E, Manches O, Dreno B, Hochman T, Rolnitzky L, Labarriere N, Guilloux Y, Goldberg J, Jotereau F, Bhardwaj N: Matrix Metalloproteinase-2 Conditions Human Dendritic Cells to Prime Inflammatory $\mathrm{T}(\mathrm{H}) 2$ Cells via an IL-12- and OX40L-Dependent Pathway. Cancer Cell 2011, 19:333-346.

doi:10.1186/2051-1426-2-S3-021

Cite this article as: Godefroy and Bhardwaj: Activation of Toll-like receptor-2 by tumor associated matrix metalloproteinase- 2 modulates dendritic cell function. Journal for ImmunoTherapy of Cancer 2014 2(Suppl 3):O21.

Submit your next manuscript to BioMed Central and take full advantage of:

- Convenient online submission

- Thorough peer review

- No space constraints or color figure charges

- Immediate publication on acceptance

- Inclusion in PubMed, CAS, Scopus and Google Scholar

- Research which is freely available for redistribution 